\title{
The Effect of Executive Compensation on Financial Performance in Egypt
}

\author{
Mohamed Adel Adam, Amr Youssef, Ahmed Mohamed Sakr \\ The Arab Academy for Science and Technology \& Maritime Transport, Alexandria, Egypt \\ Email:M_Adam_vc@hotmail.com
}

How to cite this paper: Adam, M.A., Youssef, A. and Sakr, A.M. (2019) The Effect of Executive Compensation on Financial Performance in Egypt. Open Access Library Journal, 6: e5760.

https://doi.org/10.4236/oalib.1105760

Received: September 5, 2019

Accepted: December 9, 2019

Published: December 12, 2019

Copyright $\odot 2019$ by author(s) and Open Access Library Inc.

This work is licensed under the Creative Commons Attribution International License (CC BY 4.0).

http://creativecommons.org/licenses/by/4.0/

(c) (i) Open Access

\begin{abstract}
The current research aims to propose a framework of the effects of Executive Compensation on Financial Performance, measuring the size of effect, the circumstances under which the effect is clearly observed and studying the weighted effect of Executive Compensation on the Performance of firms; ROA, ROE, Tobin's Q turning out with the outcome emphasizing whether the Executive Compensation has a significant or an insignificant role. The research sample is the top listed 50 companies in the Egyptian market which are collected as secondary data from Egypt Stock Exchange. The contribution in this research arises from measuring executive compensation role in firms of Egypt. The research tackles the whole status of the firms in Egypt during the period from 2012 to 2017. Results showed that the main hypothesis of this research that, Executive Compensation on Firm Performance is partially supported.
\end{abstract}

\section{Subject Areas}

Financial Reporting, Managerial Economics

\section{Keywords}

Board Independence, Executive Compensation, Firm Financial Performance, ROA, Egypt

\section{Introduction}

Today, the Egyptian political and economic status has several effects on firms' financial performance. Consequently, some researches prefer to ignore these years from the results to avoid different conclusions as they proposed that it was a unique governmental regulation which cannot be generalized [1]. Contradicting with previous studies, this research tackles the whole status of the firms in 
Egypt during the period from 2012 to 2017 although the fact that the data might be affected by the political and economic status of the previous years. Considering this perspective, the relationship between various financial issues and board characteristics was previously established through prior studies. Consequently, the results of prior work supposed that the board composition has an impact on financial performance. Therefore, the net effects of board characteristics on financial performance are still a point of debate that requires more investigation [1].

The existence of high-profile corporations in the developing economies within the last decades has produced a new interest in identifying measures to protect companies' financial performance [2]. It was proved that corporate governance mechanisms affect the financial reporting to guarantee identical International Financial Reporting Standards (IFRS) and to ensure reliability and credibility of corporate financial statements [3].

Much of today's corporate governance reforms trend to enhance corporate governance through upgrading the board's functioning as a result of the fact that the board of directors is considered to be an important governance device and boards are increasingly being held accountable for the organizations they govern [4]. Board size, board independence, CEO duality and size of the firm as variables of corporate governance determine the firms' performance (ROA, ROE and Tobin's Q) [5]. The contribution of this study is to examine the impact of Firm-specific; firm size, firm age, firm Leverage, and Corporate Governance; board size, board Meetings, CEO Duality, and board independence and Ownership structure; ownership insider and ownership outsider on Executive Compensation, and examine the effect of Executive Compensation on Firm Performance; ROA, ROE, Tobin's Q coming out with the result emphasizing whether the Executive Compensation has a significant role or an insignificant role.

\section{Literature Review}

The importance of executive compensation and the role of board characteristics and ownership structure in creating the optimum executive compensation system to make higher firm's financial. Several specialized and big organization synthesized many practices of governance to the assessment of the firm's characteristics. The outbreak of several high-profile corporations in both developed and developing economies within the last decades has generated a new interest in identifying measures to protect companies' financial performance and to avoid bankruptcy. One measure that had been found to show a significant amount of attention over the past two decades is executive compensation. Both academic and policy circles have devoted substantial attention to investigating the importance of executive compensation.

Moreover, it was also found that the roles of the two main elements namely influence and reciprocity were supported, in the determination of executive compensation. Influence has been declared in terms of the social capital, intellectual capital, and comparability of an executive with compensation. Reciproci- 
ty has been declared by the pay-performance relationship and the complexity of the executive role, while the relationship between influence and reciprocity has been declared by the political-symbolic role of the executives in the determination of executive compensation [6]. The influence of different ownership structure and board characteristics variables for all listed firms in Botswana stock market on firm performance was examined [7].

A regression model was developed, alternative performance measures are used as a dependent variable (e.g. ROA, ROE, LnMktCap and TOBIN'S Q). Return on assets (ROA) is an indicator of the companies' profit related to total assets. Return on equity (ROE) measures financial performance by dividing net income by shareholders' equity. Tobin's $Q$ ratio equals the market value divided by its assets' replacement cost. While ownership structure variables (e.g. sponsor directors' ownership, government ownership, institutional ownership, public ownership, and foreign ownership) are considered as the explanatory variables of interest. Besides, several control variables (e.g. industry dummy, beta, firm size, and year dummies) were also included in the prescribed model. Empirical evidence that accounting-based and hybrid performance measures are not fitted for the prescribed model (i.e. ROA, ROE and TOBIN'S Q) was provided.

The reasons for the differences in executives' compensation across industries was identified, and it was found that the compensation is significantly positively related to managerial discretion that is determined by the industrial environment. An important point was then proved in the issue of the decisive factors for executives' compensation. From the logical intuition, as previously stated about executives' compensation from the environmental and strategic perspective had a similar meaning and their idea is in coincidence with that of managerial discretion. As a very important assumption in the study of executives' compensation, the compensation must base on Marginal Productivity (MP), which is the core in economic explanation for pay. That is, individual payment should be the compensation of their benefit for the organization's net growth [8].

By introducing a unique, hand-collected executive pension data set and a detailed analysis, three objectives were proposed: the analysis of Chef Executive Officer (CEO) and non-CEO pensions extended; it was shown that the risk level of the firm is significantly dependent on the difference in payment structure between CEOs and non-CEO executives, and it was proposed that funding pensions can significantly reduce the risk-shifting agency costs associated with pension compensation. It is highly important to mention that it was determined that non-CEO executive pensions indeed matter. Evidence was presented for two observations that can improve the manner in which firms handle executive contracts in regards to agency costs: when $\mathrm{CEO}$ and non-CEO executive compensation leverage is in agreement, high leverage across the executive board amplifies the conservative effects of agency theory; and when compensation leverage is substantially different, the risk-reducing conservatism found in high-leverage CEOs is no longer observed [9]. 
Funding pensions generate significant confidence in the manager to achieve maximum pension entitlement, and it also neutralizes the conservative tendencies of the high-compensation leverage manager. Firms can then utilize this information to create contracts that best suit the company's goals. To counter risk aversion, the contracts between CEOs and non-CEO executives can either be different, or the firm can opt to fund them. Inversely, many firms may find these risk-shifting effects as a desirable reaction to higher levels of market volatility [9]. Moreover, it was also found that the roles of the two main elements namely influence and reciprocity were supported, in the determination of executive compensation. Influence has been declared in terms of the social capital, intellectual capital, and comparability of an executive with compensation. Reciprocity has been declared by the pay-performance relationship and the complexity of the executive role.

However, the relationship between influence and reciprocity has been declared by the political-symbolic role of the executives in the determination of executive compensation [6]. Funding pensions generate significant confidence in the manager to achieve maximum pension entitlement, and it also neutralizes the conservative tendencies of the high-compensation leverage manager. Firms can then utilize this information to create contracts that best suit the company's goals. To counter risk aversion, the contracts between CEOs and non-CEO executives can either be different, or the firm can opt to fund them. Inversely, many firms may find these risk-shifting effects as a desirable reaction to higher levels of market volatility [9].

Moreover, it was also found that the roles of the two main elements namely influence and reciprocity were supported, in the determination of executive compensation. Influence has been declared in terms of the social capital, intellectual capital, and comparability of an executive with compensation. Reciprocity has been declared by the pay-performance relationship and the complexity of the executive role, while the relationship between influence and reciprocity has been declared by the political-symbolic role of the executives in the determination of executive compensation [6].

Agency theory refers to the managers who work for their interest. Conflicts accrue when managers take advantage of stakeholders like earning management. Stakeholders earn fewer profits because of the managers' opportunism. Those mistakes will lead to a decrease in profit management. When this happened the value of organization stock market and share price will decrease. That managerial discretion raises the uncertainty and complexity to executives' work, and their risk, so we can believe that managerial discretion determines executives' risk. As a result, it is well known that executives' pay is closely related to the firm's performance, geographical location, the ratio of state-owned shares, industries, etc. [8]. The two key parties involved in the ongoing executive compensation discussion, executives and investors were examined.

The determinants of what executive compensation "should" be based by the interested parties were examined. That is, this focus is not on which determi- 
nants have an association with a given pay level, but rather it examines factors that the principals and agents, investors and executives, suggest have importance in determining compensation. It examines the perceptions of executive compensation determinants from the two viewpoints and identifies factors specific to each group. A highly discussed and debated area was examined in executive compensation and it notes incongruencies between the two parties, investors and executives. Specifically, it was found that investors and executives differ on the factors that should be used in the determination of executive compensation; investors place the greater emphasis on performance factors than do executives; and executives place greater emphasis on human capital factors than do investors [10].

It was also shown that agency theory is related to the problems and conflicts situations. Such as; the goal conflict between managers and ownership through opportunism issues. By focusing on these issues, agency theory was used to deduct testable hypotheses and generates empirical findings consistent with this theory. Difficult issues such as compensation in high-tech and service firms, it is not easy to monitor in all functions. It might happen in a small economy with a developing capital market [11].

Unlike agency theory, Stewardship theory takes the opposite perspective. It suggests that the agents are trustworthy and good stewards of the resources entrusted to them, which makes monitoring unnecessary since managers are not opportunistic and act in the best interests of owners, they should also be given autonomy based on trust, and this reduces the cost of monitoring and controlling their behavior [12]. Stewardship theory has its roots from psychology and sociology and is defined by Davis [13], as "a steward protects and maximizes shareholders wealth through firm performance because by so doing, the steward's utility functions are maximized". In this perspective, stewards are company executives and managers working for the shareholders, Co protects and makes profits for the shareholders.

Unlike agency theory, stewardship theory stresses not on the perspective of individualism [14], but rather on the role of top management being as stewards, integrating their goals as part of the organization. The stewardship perspective suggests that stewards are satisfied and motivated when organizational success is attained. A state-stewardship view (which competes with the agency perspective) was proposed to demonstrate manager relationship, as well as the executive compensation schemes which are under the political influence of the state. As the world's largest country considered the partial privatization of firms is most common than the state-controlled economy. It was hypothesized that Chinese executives act as responsible for the country and grow their companies to achieve firms' objectives that similar to the county's objectives [15].

Accordingly, managers' compensation schemes they want to be more loyal to the stats and abilities to make both the political objectives and the economic targets. Since the 2006 reforms, the state turned from state control through ownership to state-stewardship. The firm-level microdata was used for almost all 
public non-financial listed firms for the period 2001 to 2011 as well as regional-level macro data to examine these issues at three levels: the personal level, the corporate level, and the macroeconomic level. The lower is the compensation, the larger is the ownership stake held by the state. The lower-income will be compensated by higher gray income through colluding on tunneling activities [15]. Accordingly, managers' compensation schemes they want to be more loyal to the stats and abilities to make both the political objectives and the economic targets. Since the 2006 reforms, the state turned from state control through ownership to state-stewardship.

The firm-level microdata was used for almost all public non-financial listed firms for the period 2001 to 2011 as well as regional-level macro data to examine these issues at three levels: the personal level, the corporate level, and the macroeconomic level. The lower is the compensation, the larger is the ownership stake held by the state. The lower-income will be compensated by higher gray income through colluding on tunneling activities [15]. Moreover, stewardship theory suggests unifying the role of the $\mathrm{CEO}$ and the chairman to reduce agency costs and to have a greater role as stewards in the organization. It was evident that there would be better safeguarding of the interest of the shareholders. It was empirically found that the returns have improved by having both these theories combined rather than separated [16].

\section{Executive Compensation on Firm Performance}

Empirical evidence on the associations between executive compensation and firm performance in FTSE 350 companies over the period from 2010 to 2014 was provided, taking into account some corporate governance mechanisms within a simultaneous equation approach. A positive and significant relationship was suggested between executive compensation and firm performance. It was found that the framework of pay-performance is aligning with an agency theory approach whereby CEOs and boardroom executives are compensated for their intention to act in the best benefit of the owners based on the prior levels of corporate performance. However, it was proposed in respect to the performance-pay framework lend support to notions of the tournament whereby CEOs and board executive directors perform better in the future based on the prior amounts and structure of their compensation package or their actual managerial talents [17].

Moreover, there is a debate on regulating executive pay, especially during turbulent economic times. Although governments in developed markets have shunned the more radical proposals of compensation cuts and have left the setting of executive pay to either market mechanisms or shareholders' say-on-pay schemes, the Chinese government has issued a set of regulations to rein in the executive compensation in State-owned enterprises' SOEs, by setting a maximum level of executive compensation with reference to the average salary of employees. It was argued that legalizing executive compensation levels distorts managerial incentives and invites unintended consequences. Consequently, it 
was shown that restrictions on executive compensation are associated negatively with a firm's accounting performance. It was also demonstrated that this negative effect of compensation restriction on firm performance is ameliorated when firms adopt effective internal controls and have a high level of institutional shareholding [18].

Also, the management seems to be remunerated not for maximizing shareholder shareholders (measured by Tobin's Q) but that of the state-owned assets (measured by ROA). Moreover, compensation is not linked to ability or personality, but political connections and prestige. Additionally, internal governance mechanisms such as the percentage of independent directors and the compensation committee on the board are symbolic and do neither constrain managerial pay nor strengthen pay-for-performance. Moreover, CEO-chairman duality is used by the state to give more responsibilities to reliable state-stewards. Finally, managerial pay is closely tied to local officials' political goals and achievements, even after controlling for provincial fixed effects [15].

The Effect of Relative Performance Evaluation (RPE) on top managers compensation among firms in China is examined. The RPE is used by the private firms than the government firms and maybe this what leads to regulation of compensation and several forms of intensives. The results showed that there is a negative relation between the changes in compensation and industry performance. It was claimed that there is also a relation between the RPE and CEO turnover. As well as, if there is poor corporate governance, CEOs can affect their payments as they have the control of CEO compensation and this will lead to decrease sensibility of compensation and a lack of RPE. Finally, it was found many differences in designing the executive compensation and its evaluation for SOEs and non-SOEs as there is a regulation on cash compensation in Chinese SOEs [19].

[20] explored the impact design of executive compensation packages in Spanish firms and the function of controlling shareholders as most of them have a negative impact on the executive compensation and this result a negative effect on the firm performance and the shareholders' interest. It was examined the relationship between the ownership structure and the effectiveness of executives in term of compensations and performance and examine the motivation and incentives that are needed to expropriate the various types of most shareholders over the minority shareholders. According to executive compensation in Spain, it is considered as a difficult social process and many controlling shareholders performed inboards including the executives themselves.

Also, it was defined that the worst relation is the relation between executive compensation and performance that is happening in firms which are under control by internal shareholders and executive in boards who manage companies through confirmed the highest level of expropriation of minorities both. Finally, according to performance, no differences were achieved between organizations under internal shareholders control and firms under external shareholders control and this is explained by the existence of various types of external sharehold- 
er and several types of motives that have impacts on the effectiveness of the corporate governance and the organization performance.

The academic attention for executive compensation is increased over the last half-century and increased from 1959 to 2015. This executive compensation is categorized into two streams (the composition of pay or the level of pay). It was claimed that through the end of the world war two and to the middle of the 1970s, the executive compensation was relative. The size and determination of the relation between the wealth of executives and the performance of the organizations, they have a performance sensitivity. It was claimed that adverse selection problem that is a result of shareholders as they try to reach perfect executive to manage the firm. As well as, it was found that many literatures of executive compensation have two approaches. First one examines the structure of pay such as the compensation package for the CEO is involving salary and bonus [21].

[22] explored and analyzed executive compensation among a sample of the subsidiaries of business groups in China. Chines are applying the relative performance evaluation RPE in the compensation of the subsidiaries of business groups such as changing in performance of a subsidiary is lower than the others. The level of executive compensation is significantly lower through the private business group and level in the market is high. It was also found that the performance of the other subsidiaries affects the subsidiary's executive compensation. When there is a change in performance of one listed subsidiary is lower than other subsidiaries in the same business group, the change in executive compensation is also lower and that is an indicator that RPE is involved in decisions. It was considered the executive compensations as a core issue in organization governance as the responsibility of managers are represented in general operations and they have a great impact on the organization performance.

It also claimed that the top manager has the motive to increase his private benefits which may be influenced negatively on the interest of shareholders so the issue of the organizations' focuses on the design of the incentive mechanism which should be effective to make executives maximize their work effort and the value of the shareholders.

It was found research that explores the relation between executive compensation and firm performance. And they found that the performance of the organization is determined by the return of assets (ROA) and it is considered as an important variable along with other governance variables. It was also claimed that there is a positive relation between CEO compensation and firm performance as well as the executive compensation is affected by firms too. It was also found that executive compensation has no relation to firm performance and is not affected by it. There are known factors that affect executive compensation such as size. An absence of the relationship between compensation and performance among small firms, the relation among the large firms are important which mean there is a contrast in our observation to the underdeveloped nature of institutional (Raithatha and Komera, 2016). Consequently, this research pro- 
poses the following main hypothesis:

H1: There is a significant influence of Executive Compensation on firm performance.

This hypothesis will be divided into the following sub hypotheses:

H1.1: There is a significant influence of Executive Compensation on ROA.

H1.2: There is a significant influence of Executive Compensation on ROE.

H1.3: There is a significant influence of Executive Compensation on Q Ratio.

\section{Research Methodology}

This research follows the positivism philosophy since the research aims to test and investigate the linkage between the research variables using quantitative secondary data only. In addition, the researcher follows this philosophy to gain the advantage of fulfilling the gaps between the finding and build the research hypotheses objectively. Since the research approach adopted in this study is the deductive approach, then, the quantitative research design will be the proper choice for examining relationships between variables. This research follows quantitative study since the data used for evaluation is secondary historical data for the to plisted 50 companies in the Egyptian market.

\subsection{Data Collection and Sample Selection}

This section introduces the method of collecting data and types of data collected. The research examined the cause and effect relationship between firm's performance and executive compensation of Egyptian companies listed in the Egyptian Exchange (EGX) that reported full information for the period (2012-2017). Thus, the recent developments executive compensation is reflected in this research. This type of data is called secondary data since it is not collected for the first time by the researcher.

\subsection{Variables and Measurement}

The variables used in this study can be categorized into two main types which are; the dependent and independent variables.

Dependent Variable: The dependent variable for this study is the financial performance of firms in the Egyptian market. The performance will be measured by the Return on Assets (ROA), Return on Equity (ROE) and Tobin's Q.

Independent Variable: The independent variable employed in this study is the Executive Compensation which identified in prior research as influences performance, either positively or negatively.

This research tried to look at the possibility of the relationship between dependent variable and independent variable. The relationship between dependent variable and independent variables is explained in Figure 1.

Table 1 presents a summary for all the variables including the dependent and independent variable of the study. 


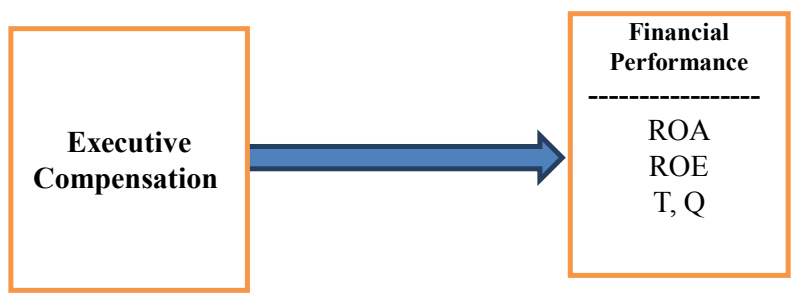

Figure 1. Relationship diagram between independent variable and dependent variable.

Table 1. Summary of dependent and independent variable.

\begin{tabular}{cl}
\hline \multicolumn{1}{c}{ Variables } & \multicolumn{1}{c}{ Measurement } \\
\hline Executive Compensation & $\begin{array}{l}\text { Measured by the average wages in the company in a certain year } \\
\text { Measured as percentage of net income after tax to total assets } \\
\text { ROA }\end{array}$ \\
MeA $=\frac{\text { Profit after tax }}{\text { Total assets }}$ \\
ROE \\
ROE $=\frac{\text { Profit after tax }}{\text { Shareholders fund }}$ \\
Measured as the market value of equity capital and the book value of \\
firm's debt divided by the book value of total assets \\
$=\frac{\text { Market Capitalization + Total assets }- \text { Shareholders fund }}{\text { Total assets }}$
\end{tabular}

\section{Results and Findings}

This section tests the relationship between Executive Compensation and Firm Performance. Firm Performance includes ROA, ROE, and Tobin's Q.

Table 2 shows the regression model for the effect of Executive Compensation on ROA. It was found that there is an insignificant effect of Executive Compensation on ROA, as the corresponding P-value is more than 0.05 and, the coefficient value is 0.000820 .

By using regression analysis, the equation could be formulated as follows:

$$
\text { ROA }=0.078995+0.000820 * \text { Executive Compensation }
$$

Thus, the first sub hypothesis of the first hypothesis that there is a significant relation between Executive Compensation and ROA is not supported.

Table 3 shows the regression model for the effect of Executive Compensation on ROE. It was found that there is an insignificant effect of Executive Compensation on ROE, as the corresponding P-value is more than 0.05 and, the coefficient value is -0.024439 .

By using regression analysis, the equation could be formulated as follows:

$$
\text { ROE }=0.504007-0.024439 * \text { Executive Compensation }
$$

Thus, the second sub hypothesis of the first hypothesis that there is a significant relation between Executive Compensation and ROE is not supported.

Table 4 shows the regression model for the effect of Executive Compensation on Tobin's Q. It was found that there is a significant effect of Executive 
Table 2. Regression model of executive compensation on ROA.

\begin{tabular}{|c|c|c|c|c|}
\hline \multicolumn{5}{|c|}{ Dependent Variable: ROA } \\
\hline Variable & Coefficient & Std. Error & t-Statistic & Prob. \\
\hline $\mathrm{C}$ & 0.078995 & 0.157621 & 0.501167 & 0.6170 \\
\hline Executive Compensation & 0.000820 & 0.013373 & 0.061290 & 0.9512 \\
\hline R-squared & 0.000025 & \multicolumn{2}{|c|}{ Mean dependent var } & 0.088533 \\
\hline F-statistic & 0.003756 & \multicolumn{2}{|c|}{ Durbin-Watson stat } & 1.303966 \\
\hline Prob (F-statistic) & 0.951211 & & & \\
\hline
\end{tabular}

The Relation between Executive Compensation and ROA.

Table 3. Regression model of executive compensation on ROE.

\begin{tabular}{|c|c|c|c|c|}
\hline \multicolumn{5}{|c|}{ Dependent Variable: ROE } \\
\hline Variable & Coefficient & Std. Error & t-Statistic & Prob. \\
\hline $\mathrm{C}$ & 0.504007 & 0.279120 & 1.805701 & 0.0730 \\
\hline Executive Compensation & -0.024439 & 0.023685 & -1.031819 & 0.3039 \\
\hline R-squared & 0.007190 & \multicolumn{2}{|c|}{ Mean dependent var } & 0.219664 \\
\hline F-statistic & 1.064651 & \multicolumn{2}{|c|}{ Durbin-Watson stat } & 1.098113 \\
\hline Prob (F-statistic) & 0.303851 & & & \\
\hline
\end{tabular}

The Relation between Board of Directors Characteristics and ROE.

Table 4. Regression model of executive compensation on Q ratio.

\begin{tabular}{ccccc}
\hline \multicolumn{4}{c}{ Dependent Variable: Tobin's Q } & \\
\hline Variable & Coefficient & Std. Error & t-Statistic & Prob. \\
\hline C & 7.243336 & 2.461269 & 2.942927 & 0.0040 \\
Executive Compensation & -0.457873 & 0.208125 & -2.199991 & 0.0299 \\
R-squared & 0.041424 & Mean dependent var & 1.896259 \\
F-statistic & 4.839960 & Durbin-Watson stat & 0.388652 \\
Prob (F-statistic) & 0.029861 & & & \\
\hline
\end{tabular}

The Relation between Board of Executive Compensation and Q Ratio.

Compensation on Tobin's Q, as the corresponding p-value is less than 0.05 and, the coefficient value is -0.457873 .

By using regression analysis, the equation could be formulated as follows:

Tobin's $\mathrm{Q}=7.243336-0.457873{ }^{*}$ Executive Compensation

Thus, the first sub hypothesis of the first hypothesis that there is a significant relation between Executive Compensation and Tobin's Q is supported. Furthermore, the fourth hypothesis that there is a significant relation between Executive Compensation and Firm Performance is partially supported.

This study examined the effect of Executive Compensation on firm financial performance on practices of listed companies in Egypt, from 2012 to 2017. The empirical results of the event study were presented in Table 5. 
Table 5. Summary of hypotheses results.

\begin{tabular}{cccc}
\hline Serial & Description & Results & Decision \\
\hline $\mathrm{H}_{1.1}$ & There is a significant relationship & Not Supported & \\
& between Executive Compensation and ROA & $\begin{array}{c}\text { Coefficient }=0.000820 \\
\text { p-value }=0.9512\end{array}$ & \\
& There is a significant relationship & Not Supported & Partially \\
$\mathrm{H}_{1.2}$ & between Executive Compensation and ROE & Coefficient $=-0.024439$ \\
& p-value $=0.3039$ & Supported \\
& There is a significant relationship & Supported & \\
$\mathrm{H}_{1.3}$ & between Executive Compensation and Q Ratio & $\begin{array}{c}\text { Coefficient }=-0.457873 \\
\text { p-value }=0.0299\end{array}$ & \\
& & &
\end{tabular}

\section{Summary, Conclusion and Recommendations}

This study examined the effect of Executive Compensation on firm financial performance on practices of listed companies in Egypt, from 2012 to 2017. The empirical results of the event study were presented.

\subsection{Recommendations and Implications of the Study}

Researchers should consider the political issues as well as economic issues as they are affecting the variables enhancing firm financial performance. Furthermore, in this research, the researcher put on his consideration the academic implication as the research examines the effect of executive compensation role between research variables and firm financial performance. Thus, researchers might consider testing other variables which may enhance the relationship between research variables and firm financial performance.

This may result in improving firm financial performance. Moreover, decision makers should highlight the role of executive compensation regarding firm financial performance despite the fact that it was proved to be insignificant, taking into consideration those political and economic issues which affect the results negatively during the period under study.

\subsection{Suggestions for Further Future Studies}

It is recommended to enlarge the studying sample and furthermore firms outside Egypt might be considered in the future, as this research analysis was applied to top 50 companies listed in the Egypt Stock Exchange which may lead to inaccurate results in the analysis process leading to inappropriate recommendations. Moreover, it might be considered in the future researches to study larger time interval as our research just focus on the period from 2012 to 2017. Therefore, some of the results might be affected positively or negatively and it is highly recommended to consider larger period in future research.

\section{Conflicts of Interest}

The authors declare no conflicts of interest regarding the publication of this paper. 


\section{References}

[1] Wahba, H. (2015) The Joint Effect of Board Characteristics on Financial Performance: Empirical Evidence from Egypt. Review of Accounting and Finance, 14, 20-40. https://doi.org/10.1108/RAF-03-2013-0029

[2] Bukair, A.A. and Abdul Rahman, A. (2015) Bank Performance and Board of Directors Attributes by Islamic Banks. International Journal of Islamic and Middle Eastern Finance and Management, 8, 291-309. https://doi.org/10.1108/IMEFM-10-2013-0111

[3] Inaam, Z. and Khamoussi, H. (2016) Audit Committee Effectiveness, Audit Quality and Earnings Management: A Meta-Analysis. International Journal of Law and Management, 58, 179-196. https://doi.org/10.1108/IJLMA-01-2015-0006

[4] Ujunwa, A. (2012) Board Characteristics and the Financial Performance of Nigerian Quoted Firms. Corporate Governance: The International Journal of Business in Society, 12, 656-674. https://doi.org/10.1108/14720701211275587

[5] Palaniappan, G. (2017) Board Characteristics Relating to Firms Performance: A Study on Manufacturing Firms in India. Journal of Commerce and Accounting Research, 6, 26.

[6] Maloa, F. (2018) Executive Compensation: Influence and Reciprocity Effects. Employee Relations, 40, 106-123. https://doi.org/10.1108/ER-04-2016-0076

[7] Dwivedi, N. and Jain, A.K. (2005) Corporate Governance and Performance of Indian Firms: The Effect of Board Size and Ownership. Employee Responsibilities and Rights Journal, 17, 161-172. https://doi.org/10.1007/s10672-005-6939-5

[8] Jing, R., Wan, Y. and Gao, X. (2010) Managerial Discretion and Executives' Compensation. Journal of Chinese Human Resources Management, 1, 17-30. https://doi.org/10.1108/20408001011051188

[9] White, R. (2018) Executive Pensions, Compensation Leverage, and Firm Risk. International Journal of Managerial Finance, 14, 342-361.

https://doi.org/10.1108/IJMF-08-2017-0172

[10] Fleming, A.S. and Christian Schaupp, L. (2012) Factor Analysis of Executive Compensation Determinants: Survey Evidence from Executives and Non-Executive Investors. Corporate Governance: The International Journal of Business in Society, 12, 16-41. https://doi.org/10.1108/14720701211191319

[11] Pereira, I.N. and Esperança, J.P. (2015) Top Executive Compensation in Less Developed Capital Markets. Corporate Governance, 15, 122-133.

https://doi.org/10.1108/CG-11-2014-0128

[12] Soliman, M. (2013) Firm Characteristics and the Extent of Voluntary Disclosure: The Case of Egypt. Research Journal of Finance and Accounting, 4, 71-80. https://doi.org/10.2139/ssrn.2311005

[13] Davis, J.H., Schoorman, F.D. and Donaldson, L. (1997) Toward a Stewardship Theory of Management. Academy of Management Review, 22, 20-47. https://doi.org/10.5465/amr.1997.9707180258

[14] Donaldson, L. and Davis, J.H. (1991) Stewardship Theory or Agency Theory: CEO Governance and Shareholder Returns. Australian Journal of Management, 16, 49-64. https://doi.org/10.1177/031289629101600103

[15] Liang, H., Renneboog, L. and Sun, S.L. (2015) The Political Determinants of Executive Compensation: Evidence from an Emerging Economy. Emerging Markets Review, 25, 69-91. https://doi.org/10.1016/j.ememar.2015.04.008

[16] Abdullah, H. and Valentine, B. (2009) Fundamental and Ethics Theories of Corpo- 
rate Governance. Middle Eastern Finance and Economics, 4, 88-96.

[17] Elsayed, N. and Elbardan, H. (2018) Investigating the Associations between Executive Compensation and Firm Performance: Agency Theory or Tournament Theory. Journal of Applied Accounting Research, 19, 245-270. https://doi.org/10.1108/JAAR-03-2015-0027

[18] Jiang, H. and Zhang, H. (2018) Regulatory Restriction on Executive Compensation, Corporate Governance and Firm Performance: Evidence from China. Asian Review of Accounting, 26, 131-152. https://doi.org/10.1108/ARA-07-2016-0080

[19] Chen, D., Liang, S. and Zhu, P. (2012) Relative Performance Evaluation and Executive Compensation: Evidence from Chinese Listed Companies. China Journal of Accounting Research, 5, 127-144. https://doi.org/10.1016/j.cjar.2012.02.002

[20] Baixauli-Soler, J.S. and Sanchez-Marin, G. (2015) Executive Compensation and Corporate Governance in Spanish Listed Firms: A Principal-Principal Perspective. Review of Managerial Science, 9, 115-140. https://doi.org/10.1007/s11846-014-0122-z

[21] Rau, R. (2017) Executive Compensation. Foundations and Trends in Finance, 10, 181-362. https://doi.org/10.1561/0500000046

[22] Zhang, Y., Cai, D., Jia, F. and Li, G. (2019) The Bounded Incentive Effect of Informal Institutions: An Empirical Study of Executive Compensation Incentives Based on the Regional Trust Environment. Nankai Business Review International, 10, 207-232. https://doi.org/10.1108/NBRI-04-2018-0024 